\title{
The Relationship between Drivers and Their Impact on Relationship Value
}

\author{
Hui-Chen Chang \\ National Taipei University \\ E-Mail: cjenny@gm.ntpu.edu.tw \\ Lin-Ju Cheng \\ St. John's University \\ E-Mail: clrvicky@mail.sju.edu.tw \\ Yen-Tsung Shih \\ National Taipei University \\ E-Mail: yentsung62@gmail.com.tw
}

\begin{abstract}
This paper integrates social network and exchange theory to discuss the effect of three relational drivers - relationship quality, relationship density, and relationship authority — on the relationship value of corporations. A study was conducted at clinic diagnostics labs in hospitals, where information was collected regarding the relationship value between different medical equipment industry suppliers. The survey data were collected from 108 medical equipment industry suppliers. The results show that suppliers who strengthened the quality of customer relationships, increased connections with customers, and enhanced the relationship with key decision makers were able to generate relationship value.
\end{abstract}

Keywords: Social Exchange Theory, Social Network Theory, Drivers of Relational Value 


\section{INTRODUCTION}

The purpose of relationship marketing is to build, maintain, and expand customer relationships and to preserve corporate profit levels (Morgan and Hunt, 1994). In a business-to-business (B2B) market, a stable long-term relationship will help raise business performance (Palmatier, et al., 2007). Many articles that discuss B2B marketing have verified the prerequisite conditions, process, and result for buyers and sellers to establish long-term partnership relations (Anderson and Narus, 1990). Crosby et al. (1990) discuss the effects between trust, commitment, relationship quality, and performance. Few studies discuss the effect of $\mathrm{B} 2 \mathrm{~B}$ relationship value has the drivers of relationship value.

This study aims to discuss the three driving factors of relationship value - relationship quality, relationship density, and relationship authority — and their effect on relationship value.

\section{METHODOLOGY}

This paper discusses the relationship effects between the drivers of relational value and relational value and relationship quality. Anderson et al. (1994) separate relationship value into four parts: economic benefit, technical benefit, service benefit, and social benefit. They use an adapted version of Lapierre's (2000) method, which uses a total of 32 measurement items.

Based on social exchange theory, trust, commitment, reciprocity norms, and exchange efficiency are four factors that comprise relationship quality, which is the main factor that affects customer relationships (Palmatier, 2008). This research uses relationship quality as the first driver and relationship density as the second diver. Customer organization can influence key decision makers in decision-making. The higher authority members in the organization will have a higher position in the social hierarchy, allowing them to act as key decision makers. Their decision-making capability with the corporation makes up the third driver of relationship value: relational authority. This study uses relationship quality, relationship density, and relationship authority as the three drivers of relationship value, with a total of eight measurement items.

This study designed a three-part questionnaire using Likert's seven-point scale for each item. The questionnaire collected data from hospitals, which surveyed the clinical biochemistry group, blood test group, and the serum immunoglobulin test group of participating clinical diagnostic labs that are key decision makers in purchases. According to the size of the hospital clinical diagnostic lab, one to three questionnaires were distributed; a total of 108 samples were collected. We used Cronbach's $\alpha$ value 
and composite reliability to measure the reliability. Other than the 0.793 capacity of the technical benefit of relationship value, the remaining Cronbach's $\alpha$ values were higher than 0.8 , showing high reliability. The composite reliability indicates that other than the capacity of technical benefit reaching 0.692 and relationship authority of 0.624 , the rest were greater than 0.7 , indicating that the variables generated a certain level of consistency.

\section{FINDINGS}

We employed confirmatory factor analysis to measure convergent validity. The results show an average greater than 0.7; therefore, the items of this study are convergent. As for discriminant validity, if the non-diagonal values of the correlation coefficient table are less than 0.95 , the table shows discriminant validity. The results of the research show a value of less than 0.95 .

From the table, model 0 has good explanation. Using regression analysis, we find that laboratory samples have no significance on relationship value $(\beta=-0.142, t=$ $-1.88, p=0.064)$. The years of interaction between laboratories and suppliers $(\beta=$ $0.160, t=2.97, p<0.01)$ and the amount of money transacted between laboratories and suppliers $(\beta=0.204, t=2.10, p<0.05)$ are significant. In model 1 , the F-value is 42.37 ( $p$-value $<0.001$ ), showing good explanation. A driver of relationship value, RQ $(\beta=0.411, t=7.551, p<0.001)$, is significant. Relationship density, $\mathrm{RD},(\beta=0.117, t=2.115, p<0.05)$ also showed statistically significance along with relationship authority $(\beta=0.20, t=3.142, p<0.01)$.

\section{CONCLUSION}

This research shows that the three drivers of relationship value (RQ, RD, RA) have a positive effect on relationship value. Thus, if businesses enhance corporate-customer relationship quality (trust, commitment, reciprocity norms, and efficiency) as well as increase relationship density (relationship channel between customer and corporations) or increase relationship authority (relationship with the higher level of authority), this will change in how customers perceive relationship value with the corporation. The effects of relationship quality influence how clinical diagnostic laboratories perceive relationship value during transactions. Therefore, it is recommended that suppliers abide by their commitments, maintain trust with customers, increase diagnostic analysis items, and promptly deliver diagnostic instruments and diagnostic reagents. 
Table 1 Empirical Results

\begin{tabular}{ccc}
\hline & Model 0 & Model 1 \\
& $\beta$ & $\beta$ \\
(t value) & (t value) \\
\hline (Constant) & $4.97^{* * *}$ & $1.13^{* * *}$ \\
& $(15.72)$ & $(3.54)$ \\
Samples & -0.142 & 0.01 \\
& $(-1.88)$ & $(0.18)$ \\
Years & $0.160^{* *}$ & 0.05 \\
Money & $(2.97)$ & $(1.69)$ \\
& $0.204^{*}$ & 0.05 \\
RQ & $(2.10)$ & $(0.85)$ \\
& & $0.411^{* * *}$ \\
RD & & $(7.551)$ \\
& & $0.117^{*}$ \\
RA & & $(2.115)$ \\
$\mathrm{F}$ & & $0.20^{* *}$ \\
$\mathrm{R}^{2}$ & $4.31^{* *}$ & $(3.142)$ \\
$\Delta \mathrm{R}^{2}$ & 0.12 & $42.37 * * *$ \\
\hline
\end{tabular}

Note: ${ }^{*} p<0.05 ; * * p<0.01 ; * * * p<0.001$

\section{REFERENCES}

Anderson, J. C., and Narus, J. A. (1990). A model of distributor firm and manufacturer firm working partnerships. Journal of Marketing, 54(1), 42-58. http://dx.doi.org/10.2307/1252172.

Anderson, J.C., Håkansson, H., and Jan, J. (1994). Dyadic business relationships within a business network context. Journal of Marketing, 58(4), 1-15. http://dx.doi.org/10.2307/1251912.

Crosby, L. A., Evans, K. R., and Cowles, D. (1990). Relationship quality in services selling: An interpersonal influence perspective. Journal of Marketing, 54(3), 68-81. http://dx.doi.org/10.2307/1251817.

Lapierre, J. (2000). Customer perceived value in industrial context. Journal of Business and Industrial Marketing, 15(2/3), 122-140. http://dx.doi.org/10.1108/08858620010316831.

Morgan, R. M., and Hunt, S. D. (1994). The commitment-trust theory of relationship Marketing. Journal of Marketing, 58(3), 20-38. http://dx.doi.org/10.2307/1252308.

Palmatier, R. W., Dant, R. D., and Grewal, D. (2007). A comparative longitudinal analysis of theoretical perspectives of interorganizational relationship performance. Journal of Marketing, 71(4), 172-194. http://dx.doi.org/10.1509/jmkg.71.4.172. 
Palmatier, R.W. (2008). Interfirm relational drivers of customer value. Journal of Marketing, 72(4), 76-89. http://dx.doi.org/10.1509/jmkg.72.4.76. 
